\title{
A Policy Brief: How Can the America COMPETES Act (2011) Better Support the Academic Success of African American Women in STEM Degree Programs?
}

\author{
Theodore Randall Sawruk \\ Department of Architecture, College of Engineering, Technology, and Architecture, University of Hartford, USA
}

Copyright $(\mathcal{C} 2015$ by authors, all rights reserved. Authors agree that this article remains permanently open access under the terms of the Creative Commons Attribution License 4.0 International License

\begin{abstract}
The U.S. became a global leader during the twentieth century, due in part to the creativity and enterprise of its engineers, scientists and inventors. Science, technology, engineering and math (STEM) professions were essential to America's past and are critical to the country's future. Currently, the U.S. has lost its competitive edge, and is no longer the world's technological leader. Our once prominent position has diminished, in part, by disparities in STEM education, primarily due to the comparatively small number of students currently pursuing STEM education and their associated careers. By increasing the number of STEM graduates, especially among under-represented groups, the federal government aspires to harness America's full potential. In 2007, President Bush signed the America Creating Opportunities to Meaningfully Promote Excellence in Technology, Education, and Science Act (American COMPETRES Act) into law. While, the American COMPETES Act (2007) covered a wide range of activities, it had little direct impact on minority STEM education opportunities. This article explores various policy issues needed to alleviate the barriers that limit the success of minority students, specifically African American women, at all levels of STEM education; and identifies specific higher education strategies that directly determine the academic success of female minority STEM college students.
\end{abstract}

Keywords STEM, America COMPETES Act, Educational Policy, African American, Female Minority Students

\section{The Need for Increased STEM Education}

The United States became a global leader during the twentieth century, due in part to the creativity and enterprise of its engineers, scientists and inventors [1]. Science, technology, engineering and math (STEM) professions were essential to America's past and are critical to the country's future. Yet today, the U.S. has lost its competitive edge, and is no longer the world's technological leader. William J. Bennett, former Secretary of Education (2012) reports that American students recently scored 23rd in math and 31st in science, when compared with 65 other top industrial countries. Our stature in STEM education has fallen behind that of Slovakia, Hungary and Estonia [2].

Our once prominent position has been challenged, in part, by disparities in STEM education, primarily due in part to the comparatively small number of students currently pursuing STEM education and their associated careers [3]. Limitations related to undergraduate and graduate collegiate access, retention and degree attainment in STEM education have become a national concern [4]. If we are to remain competitive in an increasingly dynamic, global marketplace, we must radically improve our current standing. By increasing the number of STEM graduates, especially among under-represented groups, the federal government aspires to harness America's full potential, with the intention of again making us a global force in technology and innovation $[5,6]$.

This policy BRIEF explores the college resources that prepare African Americans, specifically African American women, for successful careers in science technology engineering and math. Current research relays that the majority of African American students struggle for inclusion, attachment, and engagement in STEM programs at PWIs $[7,8]$. The America COMPETES Act represents the federal government's primary initiative to help increase minority participation in STEM degree programs [9]. However, many of the act's initiatives do not directly address campus racial climate, one of the major barriers to women of color in STEM degree programs. The intention of this brief is to draw attention to and encourage specific funding of those institutional characteristics that create a positive campus 
racial climate, and encourage the educational practices that mitigate the barriers that limit degree attainment of African American Women in STEM education $[10,11,12,13]$.

The theoretical framework of this policy brief is based on a review of recent literature related to minority success in STEM degree programs. The research method and data sources are based on a systematic search of empirical articles conducted via three online databases: Academic Search Premier, ERIC, and ProQuest Education Journals. The search limiters used were data range (2000-2014), full text documents only and peer-reviewed journals. The resultant articles were author initiated, empirical studies. Many of the publications were summary reports or position papers, which drew upon other related empirically based studies to substantiate their findings.

\section{The American COMPETES Act}

In 2007, President George Bush signed the America Creating Opportunities to Meaningfully Promote Excellence in Technology, Education, and Science Act (American COMPETRES Act) into law [14]. The over extending goal of the Act was "to invest in innovation through research and development, and to improve the competitiveness of the United States" [9]. While, the American COMPETES Act (2007), covered a wide range of activities, extended funding to 15 various government agencies, and established funds for a science and technology advisory board, it had little direct impact on minority STEM education opportunities [14]. Section 7032 of the 2007 American COMPETES Act did however, fund an extensive study into the barriers that limit the success of minority students at all levels of STEM education, with the goal of identify strategies that will bring more minorities into STEM careers.

When President Barack Obama reauthorized the America COMPETES Act in January 2011, enhancing the quality of undergraduate STEM education, and minority access, persistence, and degree completion became a national priority $[9,15]$. The America COMPETES Reauthorization Act of 2010 still gives extensive attention to research grants, STEM teacher corps, innovative manufacturing, and entrepreneurship; however, STEM education has become a more significant policy issue [4,16]. Much of the responsibility for providing federal STEM education assistance fell on the National Science Foundation and the Department of Education. Building on No Child Left Behind (ESEA), the primary STEM education policy strategies focus on K-12 achievement gaps in STEM education, school accountability, and STEM teacher training $[4,16]$. In regards to minorities and under-represented populations, the America COMPETES Act of 2010 seeks policy solutions designed to increase their participation and performance in STEM higher Education $[6,9,15,17]$. To address these issues, the America COMPETES Act of 2010 specifically focuses 2014 budget investments in undergraduate STEM education with the goal of increasing the number of well-prepared graduates with STEM degrees by one million over the next 10 years $[9,15]$. With support from Presidents Counsel of Advisors on Science and Technology (PCAST), the Obama administration has launched Catalyzing Advances in Undergraduate STEM Education (CAUSE), a 120 million dollar integrated program intended to transform undergraduate teaching and learning [9]. CAUSE goals include "improving STEM learning and learning environments, broadening participation in STEM, increasing institutional capacity, and building the STEM workforce of tomorrow" [9]. While these initiatives are commendable, they remain in the realm of over-arching generalization and do not specifically tackle the higher education issues, which directly determine the academic success of minority and under-represented STEM students. Instead, policy strategies are needed that address the relevant issues related to the low numbers of minority students enrolled in STEM curriculums, minority STEM degree abandonment, and the high minority drop-out rates in STEM bachelor's programs $[6,10,12]$.

\subsection{Enhancing the Policy Strategies}

While the America COMPETES Act of 2010 is broad in nature and far-reaching in intentions, this policy brief seeks to enhance a specific initiative focused on women and STEM education. Under Title 42: The Public Health and Welfare, Chapter 16: of the National Science Foundation, Section 1885a: Women in science and engineering; support activities by foundation for promotion, etc., the foundation is authorized to (1) support activities designed to-(A) Increase the participation of women in courses of study at the undergraduate, graduate and postgraduate levels leading to degrees in scientific and engineering fields.

\section{The Need for Minority STEM Support}

If the U.S. would like to reclaim its leadership role in STEM, colleges and universities will have to increase the number of female and minority STEM graduates, while continuing to enhance both curricular and research innovation $[18,19]$. When we examine the statistics related to STEM by race or gender, we can easily see the current disparities [3]. Statistically speaking White men and Asian Americans have traditionally been relatively successful in STEM degree attainment and therefore are not considered under-represented, as they are readily matriculating through STEM education and thrive in proceeding STEM careers [20]. Comprising only 32 percent of the population, White men make up 38 percent of all STEM doctorates and represent 55 present of all employed scientists and engineers [21].

A 2011 report, Women in STEM: An opportunity and an imperative relays that despite making up nearly half the U.S. college-educated workforce, women are vastly underrepresented in STEM careers, holding only 25 percent 
of all STEM related jobs [6]. Women also hold a disproportionately low share of STEM undergraduate degrees [22]. Moreover, women who do graduate with STEM degrees are more likely to work in education or healthcare, rather than science, engineering or technology like their male counterparts $[6,21]$

When we examine additional statistics, we discover that minority STEM graduates constitute a disproportionably low number, in comparison to the general population [22]. According to 2009 data from the National Science Foundation (NFS), Blacks are 12 percent of the U.S. population; yet, they receive just 7 percent of all STEM Bachelor's degrees, 4 percent of all Master's degrees, and only 2 percent of all $\mathrm{PhDs}$.

Although the numbers for women in general and African American women in particular, have shown a steady rise over the last decade, as related to college enrollment and undergraduate degree attainment, a significant gap still exists $[3,24,25]$. African American women continue to make-up only a minute fraction of the bloc [10]. Data from the NSF [23] reports that of all the STEM degrees conferred on women in 2012, African American women earned 10.7 percent of the Bachelor's degrees and 13 percent of the Master's degrees, but only 1 percent at the doctoral level. Finally, as encouraging as the statistic increases may be, "the percentages obscure some fields (such as mathematics), where African American female degree attainment is 800 percent less than degree-attainment levels for white females" [10].

Equally alarming are the STEM employment facts for minorities [21]. Whites comprise the largest group of STEM workers, accounting for about seven out of ten science and technology jobs [5]. While White men and White women make-up 55 and 18 percent respectively of employed scientists and engineers, Black men and Black women constitute only 2 and 1 percent of that group [21]. As such, it is not surprising that African American women currently make-up less than 1 percent of the science and engineering professionals in management positions [8,22]. With this data in mind, it is easy to see why the federal government feels it can make significant inroads into STEM degree attainment [6].

\section{Campus Racial Climate Impacts Student Success}

Recent studies conducted by educational scholars $[3,12,26]$ give valuable insight into what facilitates minority, specifically African American females' persistence and degree completion in STEM fields. Additional research $[26,27,28,29]$ shows that the majority of African American women successfully matriculate through undergraduate STEM curriculums at historically Black colleges and universities (HBCUs). While there appear to be no cognitive or academic advantages associated with attending an $\mathrm{HBCU}$ over a predominantly White institution (PWI), the support encored by a positive campus racial climate and culturally responsive teaching appears to be significant [28,30]. Additional research by Laura Perna, et al., [26, 31] and Hurtado et al., [12] connects a 'positive campus racial climate' to first generation African American Women and degree attainment in STEM.

When minorities enter predominantly White institutions (PWIs), they are often confronted with a negative or hostile campus climate $[12,9,19,32,33]$. Transitioning to a life on campus, away from the support of home, requires adjustment, belonging, and eventual attachment. Harper and Hurtado [34] report that when students are able to achieve these connections, they usually prosper both socially and academically. If they cannot make a connection, they are often discouraged, withdrawn and eventually leave [7,16,32]. Whether intentional or accidental, many minorities find themselves confronting hostile campus environments, ostracized by insensitive faculty, White peers, and culturally unrecognizable classroom pedagogy $[7,16,30,33]$. Insecure, isolated and eventually depressed, these students often abandon their educational goals and leave STEM programs [34]. This is particularly true of African American women, who have unique and personal insecurities that need to be consciously addressed both academically and socially $[7,8,34,35,36,37]$.

\section{A Unique Perspective}

When trying to understand the unique experiences of African American Women in higher education, it is vital to move beyond traditional student affairs practices, considering critical race theory and the potential for multiple identities and roles [41,42]. Many African American women have been raised with a personal framework of double oppression, with a subordinate status associated with both racism and sexism that has been historically enforced by White and Black men, as well as White women [37,39]. They often internalized traditional beliefs about women's roles, due to gender-bound upbringings, easily adopting a self-defeating perspective on life [39]. Insecurities and self-doubt, perpetuated by inequalities and stereotypes continue to plaque Black women, often interfering with their attempts to garner education and gain economic parity in contemporary society $[27,43]$. "Black women in the academy differ in their experiences, background, appearances, educational levels, demographics, occupations, and beliefs. What connects them all is the struggle to be accepted and respected members of society and their desire to have a voice that can be heard in a world of many views" [38].

\section{Policies Should Address these Specific Needs}

For more than thirty years, researchers have endeavored to 
understand the influence of organizational character $[44,45,46]$. Today, we accept that a student's personal perceptions, environmental appraisal, and coping responses are influenced by both personal factors (social-demographic variables, individual personalities and personal expectations) and environmental factors (physical surroundings, organizational structures and human aggregate) [32]. As such, the intrinsic relationship between supportive campus climates and student academic success is well understood $(11,34,35,47,48]$.

The relevant question here is, 'How does one create a campus climate that would be supportive to African American women?' This mission can be divided into two clear and distinct areas: the environmental dimension and the social-psychological dimension.

\subsection{A Diverse Campus}

The environmental dimension deals directly with compositional diversity, and the need for all colleges to increase diverse student enrollment and faculty hires [20,49]. The racial composition of college campuses significantly shapes a student's perception of place, and a familiar Genus Loci allows them to dwell within their new surroundings [43]. Christian Norberg-Schulz in Genius Loci: Towards a Phenomenology of Architecture [50] relays, "Man dwells when he can orientate himself within and identify himself with an environment as meaningful" (p. 5). Once an inclusive and supportive environment has been established, all students should be able to assimilate and prosper academically [51]. In some ways, this dimension is the easiest to achieve, as it deals with increasing numbers and rests within the control of college administrators [52].

\subsection{Faculty \& Professional Role Models}

Many African American students tend to be first generation college students, from single parent, less educated backgrounds $[29,53]$. As such, it is critically necessary for them to 'see themselves' within the academy and larger STEM professions if they are going to persevere [36]. Identification and connectivity therefore become key factors in finding truly inspirational role models [54]. Diverse role models lead the way; they mirror the same background, experiences, struggles and aspirations as minority students. For African American women, who often suffer from heightened insecurities and self-doubt, it is doubly important to find strong role models within STEM faculty and professionals $[55,56]$.

\subsection{Faculty Mentors}

In any institution of higher learning, faculty members are a critical variable. Female faculty members in STEM degree programs consciously recognize the need to be more than just outstanding scholars [11,55]. Strong academic and professional faculty-student relationships, often as friends, colleagues, and mentors, promote student confidence, security and development $[26,28,31,43]$. Since many African American students come from single-parent backgrounds, establishing external, yet intimate support from faculty mentors is central to their emotional well-being and academic success $(29,55,57]$. African American women openly acknowledge that they have a need to confide in mentors with whom they can relate and trust $[9,43]$. The value of 'othermothering' or personal nurturing of African American women by accomplished, concerned female faculty cannot be understated [56,58]. Women of color, struggling with negative racial constructs, need regular encouragement and reassurance in the form of emotional and academic support from the faculty, if they are going to persevere through rigorous STEM curriculums $[57,58,59]$.

\subsection{The Understated Value of Sisterhood}

Strong peer social networks are fundamental to a student's emotional well-being. Many African American women in STEM professions relay the hardships and isolation they endured, while matriculating through STEM degree programs $[58,60]$. African American Women must establish close bonds with fellow students if they are going to assimilate into the campus social and academic community. 'Sisterhood" is a prevailing ethos within African American culture, and strong peer support networks have a history of being vital to the success of Black women [57,59]. However, in this case, sisterhood goes well beyond the emotional support offered by close personal friendships. Instead, academic sisterhood references a cooperative rather than competitive, peer culture, one that actively sustains academic persistence and success [31].

\section{Suggestions}

Many factors contribute to creating a positive campus racial climate, and as such, they must be viewed in combination, rather than as individual initiatives. However, if the necessary campus support-networks are not in place, these students may become disenfranchised and leave. To help minority students' transition to higher education, role models, faculty mentors, and peer support networks must be present.

The primary environmental concern at many PWIs is compositional diversity, which can be achieved by continuing to provide access and enhancing enrollment for minority students. Additionally, the lack of minority faculty continues to deprive minority students of professional and academic role models, mentors, and colleagues. This deficiency can also be straightforwardly addressed by increasing minority hires, as more and more women and minorities graduate and enter STEM professions.

However, an increased minority presence alone will not resolve complex social, psychological, and academic concerns. For a positive campus racial climate to evolve and 
exist, the entire community needs to unite to support the student. Peer groups, student academic and social organizations, and racially sensitive classroom environments together serve to facilitate effective counterspaces, where African American female students can find the support necessary to repel program barriers and racial or gender microaggressions. In this way, the campus must be a physically and metaphorically safe place, a nurturing environment, where all students are able to both personally and academically explore, discover, evolve, and mature.

\section{Conclusions}

For many minorities, especially women of color, higher education is an achievement, an opportunity and a means of social, political, and economic uplift. However, many African Americans abandon STEM degrees or higher education in general, driven out of colleges by hostile campus racial climates. If the American COMPETES Act of 2010 is going to be successful in increasing the number of under-represented groups, specifically African American women, policy makers and strategists will have to directly address the complex issue of campus racial climate.

\section{Acknowledgements}

I would like to thank Dr. Diana LaRocco, EdD and the Department of Educational Leadership at the University of Hartford for their continued support, direction, and advice in the preparation of this essay.

\section{REFERENCES}

[1] U.S. Department of Education. (2013). Science, technology, engineering and math: Education for global leadership. (Issue Brief). Washington, D.C. Retrieved from http://www.ed.gov/STEM

[2] Bennett, W. J. (2012, February, 9). U.S. lags in science, math a disaster in the making. CNN Opinion on Twitter. Retrieved from

http://www.cnn.com/2012/02/09/opinion/bennett-stem-educa tion.

[3] Terris, R., Kena, G., Rathbun, A., Kewal, A. Ramani, Z. J., Kristapovich, P., \& Manning, E. (2012). Higher education: Gaps in access and persistence study. National Center for Educational Statistics, (Statistical Analysis Report) August 2012, NCES 2012046. Retrieved from http://nces.ed.gov/pubsearch/pubsinfo.asp?pubid=2012046

[4] McNaull, A. D., (2013, February). STEM education: An update and overview of policy discussions. FYI: The AIP Bulletin of Science Policy News, (21). Retrieved from Http://www.aip.org/fyi/2013/021.html?source=email

[5] Economics and Statistics Administration. (2011, September). Education supports racial and ethnic equality in STEM.
Retrieved from

http://www.esa.doc.gov/print/Reports/education-supports-rac ial-and-ethnic-equality-in-stem

[6] U.S. Department of Commerce. (2011). Women in STEM: An opportunity and an imperative. (Issue Brief). Washington, D.C. Retrieved from

http://www.commerce.gov/print/blog/2011/08/03/women-ste m-oppertunity-and-imperative

[7] Dahlvig, J. (2010). Mentoring of African American students at a predominantly White institution. Christian Higher Education, 9(5), 369-395. doi:10.1080/15363750903404266

[8] Prosper, T. (2004). African American women and the pursuit of higher education, Encounter, 17(3), 16-18.

[9] White House Office of Science and Technology Policy. (2013, April). Preparing a 21st century workforce: Science, technology, engineering and mathematics (STEM) education in the 2014 Budget. (April, 10, 2013). Retrieved from Http://www.whitehouse.gov/ostp

[10] Scriven, O. A. (2013, May). Why so few? African American women in STEM - Part II: By the numbers. The Science Foundation, Inc., Harvard Innovative Space, Retrieved from $\mathrm{http}: / /$ www.scientistafoundation.com/.../why-so-few-africanamerican-women-in-stem-part-II-by-the-numbers

[11] Hubbard, S. M., \& Stage, F. K. (2009, May/June). Attitudes, perceptions and preferences of faculty at Hispanic serving and predominantly Black institutions. The Journal of Higher Education, 80(3), 270-289.

[12] Hurtado, S., Newman, C. B., Tran, M. C., \& Chang, M. J. (2010, Winter). Improving the rate of success for underrepresented racial minorities in STEM fields: Insights from a national project. New Directions for Institutional Research, 148, 5-15. doi:10.1002/ir.357

[13] Perna, L. W., Gasman, M., Gary, S., Lundy-Wagner, V., \& Drezner, N. D. (2010, Winter). Identifying strategies for increasing degree attainment in STEM: Lessons from minority-serving institutions. New Directions for Institutional Research, (148), 41-51. doi:10.1002/ir.360

[14] America COMTETES Act, Pub. L. 110-69, (2007).

[15] America COMTETES Reauthorization Act of 2010, Pub. L. 111-358, 42 U.S.C. $\$ 1885$ a (2011).

[16] McNaull, A. D. (2012, September). White House announces plans to create a national science, math, technology, and engineering master teacher corps. FYI: The AIP Bulletin of Science Policy News, September 7, 2012(116). Retrieved from Http://www.aip.org/fyi/2012/116.html?source=email

[17] Harper, S. R. (2010, Winter). An anti-deficit achievement framework for research on students of color in STEM. New Directions for Institutional Research, 148, 63-74. doi:10.1002/ir.362

[18] Harper, S. R., \& Newman, C. B. (2010, Winter). Editors' notes. New Directions for Institutional Research, 2010(148), 1-3. doi:10.1002/ir.356

[19] Museus, S. D., \& Liverman, D. (2010, Winter). High-performing institutions and their implications for studying underrepresented minority students in STEM. New Directions for Institutional Research, (148), 17-27. doi:10.1002/ir.358 
[20] Burrelli, J. (2009). Women of color in STEM education and employment. National Science Foundation, Division of Science Resources, (CEOSE Mini-Symposium on Women of Color in STEM, October 27, 2009). Retrieved from Http://www.nsf.gov/oct/iia/activities/ceo...009/oct.27/joanbu rrelli.2pdf

[21] National Science Foundation. (2009). Women of color in STEM education and employment. National Center for Science and Engineering Statistics, Division of Science Resources. (Issue Brief). Arlington, VA. Retrieved from http://www.nsf.gov/statistics/wcse

[22] U.S. Department of Education. (2012). Fast facts: Degrees conferred by sex and race. National Center for Educational Statistics, The Condition of Education 2012 (NCES 2012-045). Washington, D.C. Retrieved from http://nces.ed.gov/fastfacts/display.asp?id $=72$

[23] National Science Foundation. (2013). African American female STEM degree and career attainment: Women, minorities and persons with disabilities in science and engineering: 2013. National Center for Science and Engineering Statistics, (Special Report NSF 13-304). Arlington, VA. Retrieved from http://www.nsf.gov/statistics/wmpd

[24] Institute of Educational Sciences. (2012, October). STEM in postsecondary education: Entrance, attrition, and course-taking among 2003-04 beginning postsecondary students. National Center for Educational Statistics (NCES 2013-152).

[25] National Center for Science and Engineering Statistics. (2005). Trends in Educational equity of girls and women: 2004 - persistence and attainment. (Issue Brief) Retrieved from http://nces.ed.gov/pubs2005/equity/Section9.asp

[26] Perna, L. W., Gasman, M., Gary, S., Lundy-Wagner, V., \& Drezner, N. D. (2010, Winter). Identifying strategies for increasing degree attainment in STEM: Lessons from minority-serving institutions. New Directions for Institutional Research, (148), 41-51. doi:10.1002/ir.360

[27] Fife, J. E., Bond, S., \& Byars-Winston, A. (2011). Correlates and predictors of academic self efficacy among African American students. Education, Project Innovation Inc., 132 (1), 141-148.

[28] Kim, M. M. \& Conrad, C. F. (2006). The impact of historically Black colleges and universities on the academic success of African-American students. Research in Higher Education, 47(4), 399-427. DOI: 10.1007/s1162-005-9001-4

[29] Wagener, U., \& Nettles, M. T. (1998). It takes a community to educate students. Change, (30), 18-25. Retrieved from http://search.proquest.com/docview/208054510?accountid=1 1308

[30] Wlodkowski, R. J., \& Ginsberg, M. B. (1995). Diversity \& Motivation: Culturally Responsive Teaching. Jossey-Bass Education Series, Jossey-Bass Social and Behavioral Science Series. San Francisco, CA: Jossey-Bass Inc.

[31] Perna, L., Lundy-Wagner, V., Drezner, N., Gasman, M., Yoon, S., Bose, E., \& Gary, S. (2009). The contribution of HBCUs to the preparation of African American women for STEM careers: A case study. Research in Higher Education, $50(1), 1-23$.

[32] Hutcheson, P., Gasman, M., \& Sanders-McMurtry, K. (2011,
March/April). Race and Equality in the academy: Rethinking higher education actors and the struggle for equality in the post-world war II period. The Journal of Higher Education, 82(2), 122-152.

[33] Sue, D. W., Capodilupo, C. M., \& Holder, A. (2008). Racial microaggressions in the life experience of Black Americans. Professional Psychology: Research and Practice, 39(3), 329.

[34] Harper, S. R., \& Hurtado, S. (2007). Nine themes in campus racial climates and implications for institutional transformation. New Directions for Student Services, (120), 7-24. doi:10.1002/ss. 254

[35] ASHE Higher Education Report. (2011). Factors that influence success among racial and ethnic minority college students in the STEM circuit, ASHE Higher Education Report. $36(6), 53-85$

[36] Sealey-Ruiz, Y. (2007). Wrapping the curriculum around their lives: Using a culturally relevant curriculum with African American adult women. Adult Education Quarterly, 58(1), 44-60.

[37] Zamani, E. M. (2003, Winter). African American women in higher education. New Directions for Student Services, (104), $5-18$.

[38] Hughes, R. L., \& Howard-Hamilton, M. F. (2003). Insights: Emphasizing issues that affect African American women, New Directions for Student Services, 104, 95-104.

[39] Howard-Hamilton, M. F. (2003, Winter). Theoretical frameworks for African American women. New Directions for Student Services, 104, 19-27.

[40] Nichols, J., \& Tanksley, C. B. (2004). Revelations of African-American women with terminal degrees: Overcoming obstacles to success, Negro Educational Review, 55(4), 175-185.

[41] Taub, D. J. \& McEwen, M. K. (1992). The relationship of racial identity attitudes to autonomous and mature interpersonal relationships in Black and White undergraduate women. Journal of College Student Development, 33, 439-446.

[42] Fries-Britt, S. L., Younger, T. K., \& Hall, W. D. (2010, Winter). Lessons from high-achieving students of color in physics. New Directions for Institutional Research, 148, 75-83. doi:10.1002/ir.363

[43] Constantine, M. G., \& Greer, T. M. (2003). Personal, academic, and career counseling of African American women in college settings. New Directions for Student Services, (104), 41-51.

[44] Allen, Walter R. (1992). The color of success: African-American college student outcomes at predominantly White and historically Black public college and universities. Harvard Educational Review, 62 (1), 26-44.

[45] Astin, A. W. (1984). Student involvement: A developmental theory for higher education. Journal of College Student Personnel, 25(4), 297-308.

[46] Tinto, V. (1987). Leaving college: Rethinking the causes and cures of student attrition. Chicago: University of Chicago Press.

[47] Hubbard, S. M., \& Stage, F. K. (2010, Winter). Identifying comprehensive public institutions that develop minority 
scientists. New Directions for Institutional Research, 148, 53-62. doi:10.1002/ir.361

[48] Wright, L. L. (2010). Social, demographic, and institutional effects on African American graduation rates in U.S. colleges and universities. (Order No. 3417790, University of North Texas). ProQuest Dissertations and Theses, 125. Retrieved from

http://search.proquest.com/docview/748814590?accountid=1 1308

[49] Cortes, C. M. (2013). Profile in action: Linking admission and retention. New Directions for Higher Education, 161, 59-69. Retrieved from http://search.proquest.com/docview/1347457546?accountid= 11308

[50] Norberg-Schulz, C. (2008). Genius Loci: Towards a phenomenology of architecture. New York City: Rizzoli.

[51] Williams, B. R. (2010, Winter). An undergraduate student of color on the study of success in STEM. New Directions for Institutional Research, 148, 105-108. doi:10.1002/ir.366

[52] Harper, S. R., Patton, L. D., \& Wooden, O. S. (2009). Access and equity for African American students in higher education: A critical race historical analysis of policy efforts. Journal of Higher Education, 80(4), 389-414.

[53] Blackwell, E., \& Pinder, P. (2014). What are the motivational factors of first-generation minority college students who overcome their family histories to pursue higher education? College Student Journal, 48(1), 45-56.
[54] Crawford, K., \& Smith, D. (2005). The we and the us mentoring African American women. Journal of Black Studies, 36(1), 52-67.

[55] Griffin, K. A., Pérez, D., Holmes, A. E., \& Mayo, C. P. (2010, Winter). Investing in the future: The importance of faculty mentoring in the development of students of color in STEM. New Directions for Institutional Research, 148, 95-103. doi:10.1002/ir.365

[56] Hinton, D. (2009, September 29). Creating community in the margins: The successful Black female academician. Springer Science + Business Media, LLC, Urban Review, 42, 394-402. DOI 10.1007/s1 1256-009-0140-3

[57] Bradley, C., \& Sanders, J. (2003). Contextual counseling with clients of color: A "sista" intervention for African American female college students. Journal of College Counseling, 6(2), 187-191.

[58] Mawhinney, L. (2011). Othermothering: A personal narrative exploring relationships between Black female faculty and students, Negro Educational Review, 62/63(1-4), 213-232.

[59] Patton, L. D. (2009). My sister's keeper: A qualitative examination of mentoring experiences among African American women in graduate and professional schools. Journal of Higher Education, 80(5), 510-537.

[60] Solorzano, D., Ceja, M., \& Yosso, T. J. (2000). Critical race theory, racial microaggressions, and campus racial climate: The experiences of African American college students. The Journal of Negro Education, 69(1/2). pp. 60-73. 